\title{
MODEL INTERNALISASI NILAI-NILAI AGAMA ISLAM PADA KEGIATAN PRAMUKA DI MADRASAH TSANAWIYAH
}

\author{
Oktio Frenki Biantoro \\ LAIN Salatiga, Indonesia \\ Email:oktiofrenkibiantoro@iainsalatiga.ac.id
}

\begin{abstract}
The internalization of Islamic religious values so far has only been carried out in classroom learning activities so that there is no synergy between Islamic religious values and scouting activities. This study aims to determine Islamic religious values in Madrasah Tsanawiyah (MTs), how to internalize Islamic religious values in scouting activities at Madrasah Tsanawiyah, and the impact of internalizing Islamic religious values on scouting activities at Madrasah Tsanawiyah. To carry out the research, the researchers used a qualitative approach. This research was carried out at MTs Ma'arif Balong Ponorogo by taking the object of Teacher Scouts in the internalization of Islamic religious values. In conducting this research, the type of research chosen is qualitative. To collect data from the various sources mentioned above, several methods were used, namely in-depth interviews, observation, and documentation. Then for the data analysis technique, the Miles and Huberman Interactive Data Analysis Model. The results of this study are (1) Islamic religious values at MTs Ma'arif Balong Ponorogo, namely the value of worship, moral values, and social values, (2) how to internalize Islamic religious values in scouting activities at MTs Ma'arif Balong Ponorogo namely by using the method of religious habituation and memorization, and (3) the impact of internalizing Islamic religious values on scout activities at MTs Ma'arif Balong Ponorogo, namely increasing faith, piety, worship, exemplary, and improving student morals.
\end{abstract}

Keywords: Internalization, Islamic Religious Values, Scouting Activities.

\begin{abstract}
Abstrak
Internalisasi nilai-nilai agama Islam selama ini hanya dilakukan pada kegiatan pembelajaran di kelas saja sehingga tidak ada sinergi antara nilai-nilai agama Islam dengan kegiatan pramuka. Penelitian ini bertujuan untuk mengetahui nilai-nilai agama Islam di Madrasah Tsanawiyah (MTs), cara internalisasi nilai-nilai agama Islam pada kegiatan pramuka di Madrasah Tsanawiyah, dan dampak internalisasi nilai-nilai agama Islam pada kegiatan pramuka di Madrasah Tsanawiyah. Untuk melaksanakan penelitian maka peneliti menggunakan pendekatan kualitatif. Penelitian ini dilaksanakan di MTs Ma'arif Balong Ponorogo dengan mengambil objek Guru Pramuka dalam internalisasi nilai-nilai agama Islam. Dalam melakukan penelitian ini, jenis penelitian yang dipilih yaitu kualitatif. Untuk mengumpulkan data dari berbagai sumber tersebut di atas, digunakan beberapa metode yaitu wawancara mendalam, observasi, dan dokumentasi. Kemudian untuk teknik analisis datanya yaitu Model Analisis Data Interaktif Miles dan Huberman. Hasil penelitian ini adalah (1) nilai-nilai agama Islam di MTs Ma'arif Balong Ponorogo yaitu nilai ibadah, nilai akhlak, dan nilai sosial, (2) cara internalisasi nilai-nilai agama Islam pada kegiatan pramuka di MTs Ma'arif Balong Ponorogo yaitu dengan menggunakan metode pembiasaan keagamaan dan hafalan, dan (3) dampak internalisasi nilai-nilai agama Islam pada kegiatan pramuka MTs Ma'arif Balong Ponorogo yaitu meningkatnya iman, taqwa, ibadah, keteladanan, dan semakin baiknya akhlak siswa.
\end{abstract}

Kata Kunci: Internalisasi, Nilai Agama Islam, Kegiatan Pramuka. 


\section{PENDAHULUAN}

Dalam perjalanannya degradasi moral dan karakter yang timbul di negera ini menjadi perbincangan yang harus dipemecahan masalahnya. Pada aspek pendidikan menjadi posisi yang menempati paling penting dalam memberikan jalan keluar terhadap masalah tersebut. Peran pemerintah dalam mendukung peningkatan kualitas pendidikan sangat diperlukan. Pendidikan dapat diartikan sebagai proses membimbing yang dilaksanakan dengan kesadaran atau proses perubahan dan internalisasikan pada ilmu pengetahuan dan nilai yang ada pada diri siswa mengarah terhadap pembentukan individu berkualitas baik. (Tafsir, 2013) Tujuan pendidikan nasional sebagaimana yang tertuang dalam UU SISDIKNAS No 20 Tahun 2003 yaitu bertujuan untuk berkembangnya potensi peserta didik agar menjadi manusia yang beriman dan bertaqwa kepada Tuhan yang Maha Esa, berakhlak mulia, sehat, berilmu, cakap, kreatif, mandiri, dan menjadi warga Negara yang demokratis serta bertanggung jawab. (Undang-Undang Sistem Pendidikan Nasional, 2003) Dalam penjelasan tersebut jika diperhatikan dari sudut pandang pendidikan Islam, yang tujuan terakhir sebuah pendidikan yaitu dapat terwujud insan kamil. (Tafsir, 2013)

Ajaran Islam bertujuan agar ada aturan untuk manusia supaya memiliki memperbaiki komunikasi yang terjadi pada seorang hamba dan Allah Swt., sebagai manusia antar manusia, serta sebagai manusia dengan seluruh ciptaannya. Sebagaimana peran dari Al-Qur'an dan Hadis yaitu digunakan untuk panduan hidup manusia dalam melaksanakan hubungan baik sebab pada AlQur'an ataupun Hadis dijelaskan bahwa terkandung nila-nilai luhur yang dapat digunakan dalam kehidupan manusia kesehariannya. (Dani, 2021). Jika dilihat dari pandangan tersebut, maka jika dikaitkan dengan pendidikan Islam terdapat nilai-nilai yang dapat diwujudkan dalam hal tauhid, pada aspek ibadah, pada aspek akhlak, dan pada aspek kemasyrakatan. Pendapat ini selaras dengan pendapat yang dikatakan oleh Zulkarnain yang memberikan pemaparan jika nilai-nilai pokok yang harus dijadikan tolak ukur dalam agama Islam yaitu nilai pada aspek tauhid, nilai pada aspek ibadah, nilai pada aspek akhlak, dan nilai pada aspek kemasyarakatan. (Zulkarnain, 2008) As'aril Muhajir juga menguatkan pendapat tersebut jika dari keempat tujuan pendidikan tersebut maka materimaterinya dapat diambil dari keempat poin tersebut. (Muhaji, 2011)

Dalam risalah Ilahiyat yang disampaikan oleh Rasul merupakan fitrah yang diturunkan (fitrah munazzalah). Kemudian fitrah majbulah merupakan fitrah yang terdapat dalam diri manusia yang sudah ada sejak penciptaannya. (Madjid, 2007) Poin besarnya adalah bentuk nilai-nilai jika berlandaskan agama harus mampu memberikan dampak dalam personal ataupun kemasyarakatan yang akan menjadi seperangkat bentuk nilai yang disajikan dalam hal kebenaran dan dapat memberikan perubahan pada aspek sikap pribadi maupun masyarakat. Dampak dari bentuk nilai pada hidup keseharian seseorang dapat dirasakan dapat berguna untuk motivasi atau prinsip guna dijadikan pedoman kehidupan. Kemudian faktanya, nilai mempunyai dampak dalam mengontrol pola sikap, pemikiran dan tingkah laku seseorang. (Kaswardi, 1988)

Kegiatan ekstrakurikuler merupakan kegiatan yang mampu memberikan bantuan pada pengembangan internalisasi nilai-nilai agama Islam di madrasah. Jika ditelaah lebih dalam ini dikarenakan pengembangan internalisasi nilai-nilai agama Islam yang bersinggungan pada aspek peningkatan manfaat otak kanan (afektif, empati, taupun rasa). Cara berfikir tentang penekanan model pembelajaran yang berkembang pada saat ini lebih condong pada aspek kognitif (otak kiri) saja, sehingga hal ini memberikan dampak perubahan cara belajar siswa yang hanya mengejar pada nilai yang bagus saja. Para siswa berlomba-lomba dalam tinggi-tinggian dalam nilai akademik. Pembelajaran yang bersifat pendidikan holistik atau menyeluruh sehingga hal ini akan menggiring 
para siswa dalam pendidikan yang terarah menuju terciptanya kualitas Sumber Daya Manusia yang berkualitas.

Dalam pembentukan karakter siswa yang religius dapat ditunjang dengan adanya kegiatan ekstrakurikuler. Ekstrakurikuler memang sifatnya kurikulum yang tidak terlihat tetapi memberikan dapak yang baik dalam pembentukan karakter siswa di sekolah. Oleh karena itu, dari salah satu perwujudan kegiatan ekstrakurikuler yang mampu mengolah karakter siswa adalah ekstrakurikuler kegiatan keprramukaan. Jika dilihat dari organisasinya maka gerakan pramuka merupakan nama organisasi yang menjadi tempat metode pembelajaran kepramukaan yang terdapat di negara Indonesia. Gerakan Pramuka ini memiliki tujuan tercapainya para anak muda Indonesia yang berkarakter baik, akhlakul karimah, berkepribadian, peduli terhadap sesama umat manusia, dan kepatuhan terhadap Negara Kesatuan Republik Indonesia (NKRI). Tugas utama dari gerakan kepramukan adalah sebagai penyelenggara dalam pendidikan kepramukaan bagi anak muda agar terbentuk sebuah generasi yang megalami peningkatan hidup. Kemudian gerakan pramuka ini memiliki fungsi yaitu sebuah lembaga pendidikan ekstrakurikuler yang berfungsi sebagai wadah dalam pembinaan dan pengembangan anak muda Indonesia. (Herucakra, 2016)

Satu-satunya organisasi pendidikan yang bersifat non-formal yang melaksanakan program pendidikan kepanduan yang diselenggarakan di Indonesia disebut gerakan kepramukaan. Ekstrakurikuler kepramukaan merupakan prosedur dari sebuah pendidikan yang berada di luar lingkungan sekolahan serta lingkungan keluarga yang berupa kegiatan pendidikan yang menarik diikuti, menyenangkan, menyehatkan, berurutan, memiliki tujuan, dan simpel yang pelaksanaannya di alam yang terbuka dengan menggunakan prinsip dasar kepramukaan dan metode kepramukaan dengan akhir tujuan dari kegiatannya yaitu untuk membentuk watak, akhlak, dan budi pekerti yang luhur. (Sarkonah, 2012)

MTs. Ma'arif Balong Ponorogo adalah salah satu satuan pendidikan dengan jenjang MTs. di Kecamatan Balong, Kabupaten Ponorogo. Dalam menjalankan kegiatannya, MTs.Ma arif Balong berada di bawah naungan Kementerian Agama. Lembaga ini juga memiliki terakreditasi A (sangat baik). Lempaga Pendidikan ini merupakan sebuah lembaga pendidikan Islam yang menitikberatkan pada kedisiplinan siswa sehingga hal ini berdampak pada disiplin yang tinggi dalam kesehariannya. Kedisiplinan MTs. Ma'arif Balong Ponorogo dapat dilihat dari beberapa hal berikut ini: kedisiplinan siswa dalam masuk sekolah, kedisiplinan siswa dalam melaksanakan shalat 5 waktu, kedisiplinan siswa dalam mengolah waktu, kedisiplinan siswa dalam mengikuti pembelajaran serta disiplin kegiatan. Hal ini tidak lepas dari internalisasi nilai agama Islam yang dilakukan oleh lembaga ini.

Berdasarkan latar belakang tersebut peneliti ingin memperdalam kajian dengan mengambil judul: "Model Internalisasi Nilai-Nilai Agama Islam Pada Kegiatan Pramuka Di Madrasah Tsanawiyah".

\section{METODE}

Untuk melaksanakan penelitian maka peneliti memilih pendekatan kualitatif. Alasan peneliti menggunakan pendekatan kualitatif disebabkan oleh pendekatan ini merupakan sebuah proses dalam penelitian yang dilaksanakan dengan cara lazim atau alamiah sesuai dengan keadaan faktual di lapangan tanpa ada kepalsuan. (Zainal, 2012) Sedangkan jenis penelitiannya peneliti menggunkan jenis penelitian studi kasus. Arikunto memberikan pandangan jika studi kasus merupakan sebuah pendekatan dalam penelitian yang memiliki sifat deskriptif, membutuhkan keintensifan dalam pelaksanaannya, dilakukan secara terperinci, dilakukan dengan tingkat kedalaman yang tinggi 
kepada personal, lembaga atau karakteristik tertentu dengan lokasi atau subyek yang tidak luas. Sedangkan K. Yin memberikan pendapat jika penelitian yang dilakukan menggunakan jenis studi kasus merupakan sebuah metode dalam sebuah penelitian yang secara spesifik mendeteksi berbagai fenomena terbaru yang terdapat dalam konteks kehidupan nyata, yang pelaksanaannya dilakukan pada waktu terjadi batasan-batasan antara fenoma dan konteksnya yang masih rancu, dengan memanfaatkan berbagai pilihan sumber data. (Gunawan, 2013)

Dalam melaksanakan penelitian, peneliti mengambil lokasi di MTs. Ma'arif Balong Ponorogo dengan mengambil objek Guru Pramuka. MTs. Ma'arif Balong Ponorogo. Lembaga ini terletak di Jl. Diponegoro No.05 Ds. Jalen Kec. Balong Kab. Ponorogo. Alasan peneliti memilih lokasi di MTs. Ma'arif Balong Ponorogo adalah karena internalisasi nilai-nilai agama Islam tidak terbatas pada pembelajaran di kelas saja tetapi juga di internalisasi melalui kegiatan Kepramukaan. Dengan pemilihan lokasi penelitian ini, peneliti mengharapkan menemukan hal-hal yang bermakna dan baru. Peneliti mengambil objek Guru Pramuka dalam internalisasi nilai-nilai agama Islam.

Kehadiran peneliti sangatlah penting jika pada penelitian kualitatif. Tugas seorang peneliti yaitu bertindak sebagai instrumen utama yang bertugas sebagai pengamat sekaligus pengumpul data. (Lincoln And Guba, 1985) Hal ini disebabkan oleh instrumen penelitian kualitatif yaitu manusia itu sendiri, yaitu seorang peneliti tersebut atau juga dapat berupa bantuan dari orang lain yang memiliki kompetensi tertentu. (Rulam, 2005) Peneliti mempunyai tugas sebagai perencana, orang yang mengumpulkan data di lokasi penelitian. Peneliti juga menjaga hubungan yang baik dan beradaptasi dengan lingkungan tempat penelitian serta informan. Keadaan ini harus dilakukan untuk menunjang kesuksesan penelitian ini dan untuk menghindarkan hal-hal yang berdampak merugikan informan. (Koentjaraningrat, 1994)

Data yang kredibel harus dikumpulkan dengan teknik pengumpulan datanya yang tepat. untuk mendukung ketepatan tersebut maka memilih teknik pengumpulan data pengamatan berperanserta (partisicipant observation), wawancara mendalam (indepth interview), dan pemanfatan dokumen. Bagian terpenting dalam sebuah penelitian terletak pada analisis datanya, sebab dari sini akan didapatkan sebuah temuan dalam penelitian. Untuk itu peneliti memilih Model Analisis Data Interaktif Miles dan Huberman. Proses analisis data dalam penelitian ini menggunakan metode induktif, yaitu menggunakan data selengkap-lengkapnya dari berbagai sumber, untuk dikembangkan menjadi sebuah teori baru. Dalam melakukan proses analisis data, dilakukan melui tiga tahap, yaitu tahap pra lapangan, selama di lapangan dan setelah selesai penelitian dari lapangan. Teknik pemeriksaan keabsahan data dalam penelitian ini adalah peningkatan ketekunan dan triangulasi.

\section{PEMBAHASAN}

\section{Nilai-nilai Agama Islam Pada Kegiatan Kepramukaan di MTs. Ma'arif Balong Ponorogo}

Ajaran Islam bertujuan agar ada aturan untuk manusia supaya memiliki memperbaiki komunikasi yang terjadi pada seorang hamba dan Allah Swt., sebagai manusia antar manusia, serta sebagai manusia dengan seluruh ciptaannya. Sebagaimana peran dari Al-Qur'an dan Hadis yaitu digunakan untuk panduan hidup manusia dalam melaksanakan hubungan baik sebab pada AlQur'an ataupun Hadis dijelaskan bahwa terkandung nila-nilai luhur yang dapat digunakan dalam kehidupan manusia kesehariannya. (Dani, 2021) jika dijabarkan dari pengertian tersebut, maka dalam pendidikan Islam aknmuncul beberapa nilai misalnya tauhid, ibadah, akhlak, kemasyarakatan. Zulkarnain memberikan penguatan jika nilai-nilai inti yang yang terkandung dalam agama Islam 
yaitu dapat berupa nilai tauhid, nilai ibadah, nilai akhlak, dan nilai kemasyarakatan. Dalam hal ini Zulkarnain menambahkan nilai tauhid dikarenakan nilai ini merupakan nilai yang sangat penting sebab sebuah nila yang menjadi hubungan manusia dengan Tuhannya (Zulkarnain, 2008) As'aril Muhajir juga menguatkan pendapat tersebut dengan memberikan argumentasi bahwa tujuan pendidikan Islam yaitu akidah/tauhid, ibadah, akhlak, dan sosial/kemasyarakatan maka materinyapun juga harus berlandaskan dari keempat hal tersebut. (Muhajir, 2011)

Nilai-nilai agama Islam pada kegiatan kepramukaan di MTs. Ma'arif Balong Ponorogo yaitu nilai ibadah, nilai akhlak, dan nilai sosial. Pada nilai ibadah para siswa diwajibkan untuk berdoa ketika acara kepramukaan akan segera dimulai. Hal ini bertujuan agar setiap kegiatan yang akan dilaksanakan supaya berjalan lancar. Para siswa mudah-mudahan diberikan Tuhan kemudahan dalam belajar baik menerima ilmu maupun mempraktekkan ilmu tersebut. Selain itu, supaya nantinya diberikan ilmu yang memberikan keberkahan dalam hidup. Dengan adanya doa ini juga para siswapun lebih tenang dalam pembelajaran. Kemudian setelah kegiatan ini selesai para siswa juga dibimbing untuk berdoa. Berdoa dilakukan tidak hanya pada awal kegiatan saja melainkan pada akhir kegiatan juga dilakukan doa Bersama. Kegiatan doa yang dilakukan baik sebelum maupun setelah kegian kepramukaan ini meningkatkan keimanan para siswa.

Dalam peningkatan aspek nilai ibadah tersebut juga diadakan hafalan surat pendek. Hafalan ini mengambil sumber yang ada pada buku SKU penggalang. Para siswa dibimbing agar hafal setiap surat pendek tersebut sebab hal ini sebagai bekal mereka dalam kehidupan bermasyarakat nanti. Dengan adanya kegiatan ini juga akan meningkatkan kemampuan hafalan siswa. Dengan optimalisasi hafalan pada kegiatan kepramukaan ini juga membantu menguatkan hafalan siswa yang juga dilaksanakan pada kegiatan pembelajaran yang ada di kelas. Siswa yang tidak hafal dalam pembelajaran di kelas akan lebih menguasai pada kegiatan kepramukaan. Segala sesuatu jika dilakukan secara berulang-ulang akan membuat para siswa akan lebih mudah untuk hafal.

Kegiatan shalawatan juga dilaksanakan sebagi wujud nilai ibadah dalam kegiatan kepramukaan. Kegiatan shalawatan ini sebagai mewujudkan rasa cinta seseorang terhadap junjungan kita Nabi Muhammad Saw. yang dapat bernilai ibadah. Shalawat juga merupakan perintah Allah Swt. sehingga dalam pembelajaran pun harus dilaksanakan agar mendapatkan pahala sebagai bekal kita nanti di akhirat. Para siswa pun antusias dalam kegiatan ini sebab sudah ditanamkan sejak dini akan kecintaan kepada Nabi Muhammad Saw., sehingga dalam pelaksanaannya para siswa tidak dipaksa sedemikian rupa agar para siswa mau bershalawat. Kesadaran yang ada padi diri siswa ini perlu ditanamkan agar nantinya dalam kehidpan sehari-hari yang ada di masyarakat mereka dapat terbiasa dan tidak dipaksa lagi. Segala sesuatu yang datang dari hati tidak akan menimbulkan keterpaksaan.

Dalam hal akhlak para siswa diajarkan dalam menjaga Akhlak yaitu menghormati kepada guru sebab guru adalah orang yang menjadi perantara bagi datangnya ilmu bagi siswa. Dibutuhkan perhatian siswa yang lebih untuk menjalankan akhlak menghormati kepada guru agar berjalan dengan baik yaitu ketika bertemu mengucapkan salam sebab salam merupakan ucapan yang mengandung doa. Selanjutnya adalah berjabat tangan dengan mencium tangan para guru. Hal ini menunjukkan sikap yang baik sebab menunjukkan sikap yang tawadhu. Apabila guru sedang berbicara maka kita mendengarkan dengan penuh semangat, tidak memotong pembicaraan guru. Apabila sedang berbincang-bincang dengan guru maka hendaknya menggunakan kata-kata yang santun serta yang paling penting yaitu taat terhadap perintah guru. 
Selain mengajarkan taat kepada seorang guru juga dalam hal akhlak para siswa diajarkan untuk hormat dan patuh terhadap orang tua masing-masing. Tugas seorang anak memang untuk mentaati terhadap orang tuanya sebab hal ini merupakan akhlak yang tinggi dalam ajaran Islam. Bahkan ridha Allah Swt. berada pada ridha kedua orang tuanya. Selama orang tua tersebut memerintahkan kita untuk melakukan kebaikan maka kita memiliki kewajiban untuk mentaatinya, tetapi jika orang tua tersebut menyuruh untuk berbuat maksiat maka kita tidak boleh mentaatinya. Tidak ada kepatuhan terhadap kemaksiatan. Para siswa juga dianjurkan ketika berjabat tangan dengan kedua orang tuanya hendaknya mencium tanganya meskipun orang tuanya bekerja serabutan yang mengakibatkan tangannya kotor maka tetap mencium tangannya sebagai wujud bakti kita kepada kedua orang tua.

Sedangkan dalam hal sosial kemasyarakatan para siswa dibimbing untuk kerja bakti. Kegiatan ini mengajarkan para siswa agar memiliki kepekaan sosial yang tinggi. Kepekaan yang dimaksud yaitu kepekaan terhadap kebersihan lingkungan. Para siswa ditugaskan untuk memungut sampah yang berserakan yang ada pada lingkungan sekolahan dan sekitarnya. Kerja bakti ini akan menumbuhkan sikap gotong royong antar siswa. Para siswa bekerjasama dalam membersihkan lingungan sekolah dan sekitarnya. Selain itu, kebersihan yang ada di lingkungan sekolah dan sekitarnya sebab kebersihan ini merupakan bagian dari keimanan seseorang.

Selain kerja bakti, para siswa juga melakukan kegiatan santunan kepada orang fakir miskin dan anak yatim piatu yang dalam hal ini disebut dengan kegiatan bakti sosial. Dalam kegiatan ini memiliki tujuan agara para siswa memiliki rasa cinta kasih terhadap sesama, terutama sesama yang memiliki kekurang dalam hal finansial. Kegiatan ini juga akan menimbuklkan jiwa saling tolong menolong dalam diri siswa, sehingga hal ini akan memberikan dampak kepedulian siswa terhadap sesamanya yang mengalami sedang kurang beruntung. Jiwa dermawan seorang siswa akan terasah dalam kegiatan bakti social ini sebab mereka merasakan langsung atau bersentuhan langsung dengan masyarakat yang membutuhkan uluran tangan para dermawan.

Jika dilihat dari strukturnya maka dapat dijelaskan jika pada aspek nilai agama Islam maka dapat dikatakan materi yang dapat direalisasikan pada pengalaman jasmani dan rohani. Selain itu juga dapat diartikan sebagai kepribadian yang utuh guna menggapai manusia yang sempiurna (insan kamil). Kemudian njika dilihat dari sifat-sifatnya nilai ini juga memiliki yang kebenarannya tidak diragukan lagi, komprehensif, dan murni. Agama Islam memiliki benenaran dan kebaikan yang berada pada diatas akal, emosional, harapan, dan hasrat seseorang serta dapat melebihi lapisan, suku, masyarakat pada umumnya. (Kamus Besar Bahasa Indonesia, 1989)

Al-Quran dan Hadis dijadikan sumber utama dalam mengarahkan manusia ke untuk menggapai ridha Allah Swt. Al-Syaibani memberikan pandangan terhadap tujua yang dilakukan dalam aktivitas ibadah seseorang yaitu: (1) Individu, dari tujuan ini akan diperoleh pengalaman individu yang bersifat akhlak seseorang yng semakin baik, jasmani dan rohani, dan apa saja yang harus dipersiapkan dalam menghadapi kehidupan baik di dunia dan akhirat. (2) Kemasyarakatan, pada tujuan ini maka diperlukan kemanpuan dalam tata cara seseorag dalam bersikap pada masyarakat, peralihan hiudp yang ada pada masyarakat, dan meningkatkan pengalaman msyarakat. (3) Profesional, pada tujuan ini memiliki keterkaitan dengan adanya pola Pendidikan dan pembelajaran yang beroientasi pada aspek ilmu pengetahuan, profesi, seni, dan kemasyarakatan. (Tafsir, 2008)

Akhlak merupakan cara kita dalam mengelola intelektual dan budi pekerti yang luhur melalui kegiatan yang memerlukan kretifitas dengan tetap mempertimbangkan cipta, karsa, dan karya. Pemeliharaan terhadap idealism dalam diri seseorang tentunya harus dipelihara dengan baik, sebab 
hal ini akan berpengaruh terhadap kehidpan yang terjadi pada seseorang baik itu di dunia dan di akhirat kelak. (Saebani dan Hamid, 2010) dari sinilah akan terwujud menigkatnya kemampuan seseorang dalam bergaul dengan sesame melalui kegiatan silaturahim yang terjalin dengan baik, sehingga mampu menjalin persaudaraan sesama manusia yang ada di muka bumi. Mengingat akan pentingnya persaudaraan sesama muslim ini maka perlu perwujudan sebagai berikut: (1) ukhuwah bashariyah, dalam ukhuwah ini manusia dikatakan bersaudara apabila berlandaskan prinsip pada sikap persamaan derajat. (2) ukhuwah insaniyah, dalam ukhuwah ini manusia dikatakan bersaudara apabila berlandaskan pada akhlak dan kemampuan dalam memahami kekurangan dan kelebihan seseorang. (3) ukhuwah wathaniyah, dalam ukhuwah ini manusia dikatakan bersaudara apabila berlandaskan nilai- nilai kebersamaan yang terjadi pada persaudaraan yang ada pada ruang lingkup antar negara yang ada di dunia ini.

\section{Cara Internalisasi Nilai-Nilai Agama Islam dalam Kegiatan Kepramukaan di MTs. Ma'arif Balong Ponorogo}

Dalam pembelajaran Pendidikan Agama Islam (PAI) sangat pengtinya internalisasi nilai yang harus dilakukan lembaga pendidikan di sekolah masing-masing, sehingga dalam pengajaran tersebut mampu merasuk ke dalam jiwa para siswanya. Dari sinilah awal mula pendidikan yang ditanamkan itu bermula guna menciptakan insan yang religius sebab arah dari pengembangan yang dilakukan berdasarkan ajaran agama Islam. Apalagi jika kita melihat dalam arus globalisi seperti saat ini maka sangat diperlukan nilai-nilai moral agama yang akan menjadi landasan seseorang guna menghadapi tantangan tersebut. (Nurdin, 2014)

Cara internalisasi nilai-nilai agama Islam dalam kegiatan kepramukaan di MTs. Ma'arif Balong Ponorogo dengan menggunakan metode pembiasaan keagamaan dan hafalan. Dengan metode tersebut para siswa nilai-nilainya akan tertanam melalui kegiatan yang ada di madrasah sehigga nantinya dapat mereka lakukan di dalam kehidupan sehari-hari. Kegiatan yang ada di madrasah tentunya akan dibimbing oleh para guru, tetapi ketika nanti berada di rumah akan dibimbing oleh para orang tua serta tokoh masyarakat yang ada.

Metode pembiasaan keagamaan merupakan suatu metode yang dipilih oleh lembaga ini sebab dirasakan paling tepat dalam menyentuh keagamaan anak. Prosesnya adalah para siswa dibiasakan dalam kegiatan yang bersifat keagamaan. Setiap siswa dibiasakan melaksanakan kegiatan keagamaan tersebut agar nantinya mereka terbiasa dalam melakukan kebaikan. Orang yang terbiasa melakukan kebaikan, mereka tidak akan dipaksa lagi dalam melakukan kebiasaan baik itu sebab sudah terbiasa melakukannya. Mereka melakukannya dengan dorongan yang ada pada hati mereka. Lain halnya jika para siswa tidak terbiasa dengan kegiatan keagamaan. Mereka perlu dibiasakan agar mampu terbiasa dan ini membutuhkan banyak waktu, sehingga dengan adanya kegiatan ini metode pembiasaan keagamaan dapat dilakukan dengan baik.

Lembaga pendidikan seperti ini merupakan tempat yang paling tepat untuk melakukan kebiasaan-kebiasaan baik dalam rangka meningkat religious seseorang. Dengan adanya nilai religious yang sudah tertanam dalam diri seseorang melalui program pembiasaan tesebut maka akan menjadi bekal bagi siswa dalam menghadapi kehidupan yang tidak mudah ini, sehingga kebiasaankebiasaan baik ini akan menjadi kontrolnya jika pada suatu saat digoda dengan hal-hal yang tidak baik. Seseorang yang jiwanya sudah mapan maka tidak akan mudah tergoda dengan kenikmatankenikmatan sesaat yang akan merusak masa depan yang gemilang.

Pembiasaan keagamaan merupak metode yang cukup baik, seba orang yang memiliki kebiasaan baik akan memiliki spontanitas yang telah ada dalam diri seseorang maka dari itu 
seseorang tersebut tidak akan diperintahkan lagi dalam melakukan kebaikan. Terjadi banyak perubahan jika para siswa melakukan kegiatan pembiasaan ini. Kebiasaan akan timbul jika mereka melakukan kegiatan dengan cara mengulanginya beberapa kali. Apalagi metode pembiasaan keagamaan ini dilakukan setiap minggunya dalam kegiatan kepramukaan ini sudah pasti akan menjadikan para siswa terbiasa dengan kegiatan keagamaan yang sudah ada di lembaga. Hal ini akan memudahkan para guru dalam pembelajarannya sebab mereka tidak perlu banyak keluar energiya untuk memberikan pemahaman terhadap para siswanya, sebab para siswa sudah tidak kesulitan lagi beradaptasi dengan lingkungan sekolahnya.

Jika dilihat sebuah pembiasaan maka akan dikatakan jika pembiasaan keagamaan yang dilakukan dapat dikatakan sebuah metode yang sangat baik untuk dilakukan sebab akan memunculkan tindakan-tindakan spontan yang terbiasa dilakukakannya dalam kehidupannya, sehingga hal ini akan mengakibatkan kepekaan seseorang dalam melaksanakan kebaikan tanpa diperintah lagi oleh orang yang punya kewenangan apalagi perlu hukuman dari seseorang agar melalukan kebaikan itu. Siswa yang mengikuti proses melaksanakan pembiasaan yang baik dalam hal keagamaan banyak mengalami perubahan dalam hidupnya sebab kegiatan pembiasaan pada prakteknya dilakukan secara berulang-ulang kali sehingga memerlukan waktu yang cukup lama. Waktu yang cukup lama ini yang pada akhirnya akan membuat para siswa akan terbiasa dan mempersiapkan diri untuk melaksanakan kegiatan tersebut. Ketika siswa sudah mampu untuk beradaptasi dengan kebiasaan keagamaan tersebut maka peran dari guru sudah tidak terlalu berat, sehingga energi guru dapat digunakan untuk memaksimalkan kegiatan yang lain, misalnya memaksimalkan dalam menyiapkan materi pembelajaran yang baik. Kegiatan pembiasaan yang dilakukan di lembaga pendidikan biasanya dilakukan setiap hari atau setiap minggu sehingga hal ini membuat para siswa sudah terbiasa dan hafal kegiatan keagamaan yang sudah ada di lembaga.

Sedangkan metode yang kedua adalah metode hafalan. Metode ini sengaja dipilih sebab para siswa tidak perlu lagi berat-berat membawa buku catatan dalam pembelajaraanya karena mereka sudah hafal dalam ingatannya. Guru tinggal mengajak para siswa untuk membaca berulang-ulang kali sampai siswa itu hafal. Para siswa mengikuti apa yang diucapkan gurunya dengan bersama-sama teman satu regu. Hal ini jika tidak hafal karena bersama-sama maka akan menular menjadi hafal. Tujuannya adalah agar para siswa mampu mengingat materi surat-surat pendek, ayat-ayat pendek, dan doa-doa pilihan.

Materi semacam surat-surat pendek, ayat-ayat pendek, dan doa-doa pilihan perlu juga dikuatkan pada kegiatan keparamukaan seperti ini agar para siswa lebih cepat dalam hafalannya. Dengan demikian apa yang menjadi tujuan dari pembelajaran akan lebih cepat selesai. Ketika mereka sudah hafal dengan materi yang diberikan oleh guru, ini berarti metode pembejaran semacam ini cukup mantab jika digunakan dalam pembelajaran. Setelah mereka hafal mereka juga mereka juga dituntut untuk memahami apa maksud yang ada dari hafalan tersebut, sehinga mereka juga mampu mengetahi maknanya.

Jika dilihat dari teorinya maka pembiasaan dapat diartikan sebagai cara dalam menanamkan kebiasaan baik. Metode ini dapat dikatakan sebagai metode yang paling ampuh jika diterapkan bagi seseorang. Pada akhirnya seseorang yang sudah terbiasa dalam melakukan kebaikan maka akan terjadi rasa senang hati dan kemudahan dalam melaksanakan kebaikan.(Aly, 1999) ketika berbicara soal kebiasaan maka kebiasaan ini dapat dikatakan sesuatu hal yang sangat istimewa dalam kehidupan seseorang sebab ketika seseorang sudah mampu melakukan kebiasaan-kebiasan yang telah mengakar maka dapat memberikan sumbangsih pada kegiatan-kegiatan yang ada di luar 
ruangan misalnya bekerja, memproduksi, dan mencipta. (Quthb, 1993) Pada akhirnya para siswa yang sudah menjalani proses pembelajaran maka apa yang menjadi kebiasaan-kebiasaan dalam dirinya akan mengalami perubahan kea rah yang lebih baik. Burghardt menguatkan pendapat tersebut dalam sebuah teori yang mengatakan jika kebiasaan itu dapat mucul sebab adanya pengurangan kecendurungan respons dengan menerapkan motivasi yang dilaksanakan dengan cara pengulangan dalam prosesnya.(Syafaat, 2008) Islam mempergunakan kebiasaan itu sebagai salah satu teknik pendidikan, lalu mengubah seluruh sifat-sifat baik menjadi kebiasaan sehingga jiwa dapat menunaikan kebiasaan tanpa terlalu menguras banyak energi dan tanpa menemukan banyak kesulitan. (Syafaat, 2008)

Jika dilihat dari pengertiannya maka hafalan dapat dikatakan sebagai segala hal yang sanggup dihafalkan dan sudah masuk dalam ingatan seseorang serta orang tersebut dapat melafalkannya tanpa melihat teks sama sekali. (Poerwadarminta, 1986) Sedangkan jika dikatakan metode hafalan maka dapat dijelaskan suatu metode yang gunakan oleh seorang guru agar siswa mampu menghafal sejumlah kalimat tertentu sesuai dengan arahan dari guru. (Muji, 2008) Dalam ajaran agama Islam, metode hafalan ini sangatlah penting untuk digunakan dalam pembelajarannya, sebab dalam agama Islam banyak hal yang perlu dihafalkan misalnya: surat-surat pendek, hadis nabi, ataupun doa sehari-hari. Untuk penerapan metode ini maka guru juga harus mempertimbangkan bagaimana tingkat sumber daya manusia yang akan menjadi target Pendidikan. (Uhbiyati, 1998)

\section{Dampak Nilai-Nilai Agama Islam Pada Kegiatan Kepramukaan di MTs. Ma'arif Balong Ponorogo}

Dampak nilai-nilai agama Islam pada kegiatan kepramukaan di MTs. Ma'arif Balong Ponorogo adalah meningkatnya iman dan taqwa siswa serta semakin baiknya akhlak siswa. Peningkatan iman siswa dapat dilihat pada pada aspek para siswa dalam menjalankan shalat 5 waktu. Para siswa tertib dalam menjalankan shalata 5 waktu. Shalat dapat dijadikan tolak ukur dalam amal seseorang sebab shalat merupakan tiang agama. Jika shlatanya baik maka tegaklah agamanya tetapi jika shalatnya rubuh maka rubuhlah agamanya. Orang yang menjalankan shalat dapat dikatakan pribadi yang taat kepada Allah Swt., sebab shalat merupakan perintahnya Allah Swt. Shalat merupaka saran akita mengingat Allah Swt. dan akan membuat hati kita menjadi tenang. Shalat juga sebagai perisai bagi seorang muslim sebab dengan aktif kita menjalankannya maka kita akan terhindar dari sifat keji dan mungkar.

Orang yang rajin berdoa sebelum dan setelah kegaiatan akan meningkatkan keimanan dan ketaqwaan seseorang sebab dengan adanya dos tersebut akan mendatangkan rahmat dari Allah Swt. Orang yang mendapatkan rahmat dari Allah Swt., akan ditambah iman dan taqwanya. Selain itu, dia akan akan mendapatkan kekuatan dalam menghadapi musuhnya. Orang yang sebelumnya takut dengan musuh-musuhnya sebab imannya telah meningkat maka akan muncul keberanian dalam dirinya. Orang yang rajin berdoa juga akan terhindar dari sifat kejelekan sehingga hal ini akan meningkatkan iman dan taqwa mereka. Kegiatan shalawatan juga mampu meningkatkan keimanan dan ketaqwaan siswa. Hal ini terbukti sebab terkandung perintah Allah Swt., sebagai wujud kecintaan kita kepada Nabi Muhammad Saw. yang dapat bernilai ibadah sehingga dalam pembelajaran pun harus dilaksanakan agar mendapatkan pahala sebagai bekal kita nanti di akhirat. Orang yang rajin bershalawatan ini akan terbiasa bershalawatan dimanupun mereka berada sehingga meningkatkan iman dan taqwa para siswa.

Kegiatan hafalan yang terapkan oleh lembagai ini juga berpengaruh dalam peningkatan iman dan taqwa siswa. Orang yang hafal surat-surat pendek akan senantiasa membacanya ketika dalam 
kondisi terdesak, misalnya ketakutan di malam hari tentunya mereka akan membaca surat-surat pendek yang mereka hafal. Hal ini tentunya menanmbah iman dan taqwa sebab telah mengingat Allah dalam kondisi yang darurat. Lain halnya jika mereka membaca amalan-amalan yang tidak ada dasarnya yang menjadikan mereka muysrik. Mereka juga akan meningkat iman dan taqwanya ketika membaca doa-doa harian yang dihafalkan setiap kegiatan. Ketika mereka hendak makan akan berdoa sebelum makan dan ketika selesai makan mereka akan berdoa setelah makan. Begitu pula dengan melakukan kegiatan yang lainnya. Hal ini sangat baik dilakukan dari pada mereka tidak membaca doa sama sekali.

Dalam hal akhlak pun mereka mengalami peningkatan. Hal ini terlihat ketika mereka hendak berangkat menuju sekolah mereka perpamitan dan bersalaman sambal mencium tangan kedua orang tuanya. Sikap mencium tangan kedua orang tuanya ini menunjukkan akhlak yang baik sebab hal ini menunjukkan sikap menghormati orang tua. Setelah mereka berangkat mereka juga mengucapkan salam kepada kedua orang tuanya. Hal ini juga terlihat ketika mereka datang ke sekolah mereka mengucapkan salam, berjabat tangan dengan guru dan mencium tangn guru sebagau wujud takdim kepada guru. Apabila guru sedang berbicara maka kita mendengarkan dengan penuh semangat, tidak memotong pembicaraan guru. Apabila berbicara dengan guru menggunakan kata-kata yang sopan dan yang paling penting yaitu taat terhadap perintah guru. Hal ini menunjukkan peningkatan akhlak siswa yang dilakukan baik di rumash maupun di sekolahan.

Dalam hal social kemasyarakatn juga terlihat peningkatannya. Hal ini terlihat ketika siswa bergotong-royong memberihkan lingkungan sekolah. Membersihkan lingkungan sekolah dari sampah merupakan kegiatan yang sangat baik sebab sebgai wujud menjaga kebersihan lingkungan juga sebagai wujud cinta akan kebersihan. Selain kerja bakti, para siswa juga melakukan kegiatan santunan kepada orang fakir miskin dan anak yatim piatu yang dalam hal ini disebut dengan kegiatan bakti sosial. Dalam kegiatan ini memiliki tujuan agara para siswa memiliki rasa cinta kasih terhadap sesama, terutama sesama yang memiliki kekurang dalam hal finansial. Kegiatan ini juga akan menimbuklkan jiwa saling tolong menolong dalam diri siswa, sehingga hal ini akan memberikan dampak kepedulian siswa terhadap sesamanya yang mengalami sedang kurang beruntung. Jiwa dermawan seorang siswa akan terasah dalam kegiatan bakti social ini sebab mereka merasakan langsung atau bersentuhan langsung dengan masyarakat yang membutuhkan uluran tangan para dermawan.

Kualitas dalam mengajar seorang guru dalam kegiatan pembelajaran tentunya harus selalu ditingkatkan. Hal ini merupakan tugas seorang guru dalam proses pembangunan manusia memperoleh posisi pada garda terdepan. Tugas seorang gurunya tentunya tidak hanya mentransfer ilmu kepada siswwa saja, melainkan agar memberikan dampak yang signifikan dalam pembinaan mental kepribadian siswa yang nantinya dapat berguna dalam pembangunan bangsa dan negara yang seutuhnya baik jasmani maupun rohani. (Wahyudi, 2012) Ketika seseorang mengatakan dirinya beriman maka tentunya kita akan dituntut untuk menerima secara pasti dan sadar terhadap apa yang telah diperintah Allah dan Rasulnya serta tetap menjalankan dengan rasa penuh tanggungjawab. Agar keimanan seseorang mengalami kesetabilan dan dapat istiqamah dalam menjalan perintah Allah Swt., maka dalam pelaksanaan perintahnya itu digunakan sebagai alat komunikasi seseorang agar senantiasa mantab, berfungsi dengan baik, dan terarah yang benar. (Ali, 2011)

Pengamalan dan pembelajaran keimanan dan ketaqwaan dalam kehidupan sehari-hari sangat dibutuhkan seseorang. Bagi seorang mukmin, iman kepada Allah Swt., merupakan sebuah 
kebutuhan pokok yang harus terpenuhi. Sumber utama dalam menegakkan ajaran agama Islam adalah keimanan seseorang. Dengan adanya keimanan seseorang akan menerima ajaran agama Islam dengan baik sehingga seseorang akan merasa sepenuh hati dalam menjalankan perintah Allah Swt. Selain keimanan seseorang tetaqwaan memperoleh tempat yang sangat penting dalam ajaran agama Islam. Taqwa dapat dikatakan sebagai pokok segala pekerjaan bagi seorang muslim. (Ali, 2011)

Tugas dalam meningkatkan keimanan dan ketaqwaan seseorang merupakan tugas bagi semua orang muslim. Dalam pelaksanaan iman dan taqwa maka Allah Swt., memerintahkan agar masuk dalam pelaksanaan ibadah sehari-hari. Dalam tahapan selanjutnya setelah keimanan dan ketaqwaan seseorang maka tahap selanjutnya dalah perlu adanya peningkatan pengamalan dalam ibadahnya sebab iman seseorang kadang-kadang mengalami kenaikan dan penurunan. Buah dari keimanan dan ketaqwaan seseorang maka dapat dilihat dari aspek akhlaknya. Sumber utama dari akhlak seseorang adalah ajaran Allah dan Rasul-Nya. Tolak ukur dari kebaikan atau keburukan seseorang dapat dilihat dari akhlaknya.

Akidah dan Syariah yang baik akan menghasilkan akhlak yang baik pula. Hubungan antara Tuhan dan hambanya pada dasarnya mengalami keterkaitan dalam asal mula kejadian manusia tersebut. Sesuai dengan fitrahnya bahwa nabi Muhammad Saw., diutus untuk menyempurnakan akhlak. Dalam proses penyempurnaannya perlu adanya sebuah tahapan sebab pada dasarnya akhlak terbagi menjadi bermacam-macam misalnya akhlak baik dan akhlak buruk. Nabi Muhammad Saw., ketika diutus oleh Allah Swt., untuk menyempurnakan akhlak maka beliau sudah memiliki akhlak yang sempurna. Hal ini menjadi teladan bagi kita semua ketika mengajarkan akhlak yang baik maka kita juga harus memperbaiki akhlak kita terlebi dahulu. (Makbuloh, 2012) Akhlak merupakan materi yang bersifat praktis dan langsung dapat dipraktekkan dalam kehidupan sehari-hari. Dalam melaksanakan akhlak ini diperlukan keluwesan agar dapat membimbing seseorang kearah yang lebih baik (Abdurahman, 2016)

\section{SIMPULAN}

Berdasarkan paparan data dan analisis data tersebut maka dapat disimpulkan bahwa nilai-nilai agama Islam di MTs. Ma'arif Balong Ponorogo yaitu nilai ibadah, nilai akhlak, dan nilai sosial yang diwujudkan dalam pengalaman rohani dan jasmani. Cara internalisasi nilai-nilai agama Islam pada kegiatan pramuka di MTs. Ma'arif Balong Ponorogo yaitu dengan menggunakan metode pembiasaan keagamaan dan hafalan. Kegiatan yang ada di madrasah tentunya akan dibimbing oleh para guru, tetapi ketika nanti berada di rumah akan dibimbing oleh para orang tua serta tokoh masyarakat yang ada. Dampak internalisasi nilai-nilai agama Islam pada kegiatan pramuka MTs. Ma'arif Balong Ponorogo yaitu meningkatnya iman, taqwa, ibadah, keteladanan, dan semakin baiknya akhlak siswa.

\section{DAFTAR PUSTAKA}

Abdurahman, Muhamad. (2016). Akblak. Jakarta: PT. Raja Grafindo Persada. Ali, Daud. Mohammad. (2011). Pendidikan Agama Islam. Jakarta: Rajawali Pers.

Anggatra Herucakra Aji, "Pendidikan Karakter dalam Ektrakurikuler Pramuka di SMP Negeri 1 Yogyakarta”, Jurnal Kebijakan Pendidikan. 2016. Vol. V, 84.

Arifin, Zainal. (2012). Penelitian pendidikan metode dan paradigma baru. Bandung: PT Remaja Rosdakarya Offset. 
Dani, A. R. (2021). Development Of Religious Characters And Attitudes Of Nationalism In SMP Negeri 6 Kota Salatiga. Afeksi: Jurnal Penelitian dan Evaluasi Pendidikan, 2(1). Jurnal Afeksi, 16-23.

Depdibud. (I989). Kamus Besar Bahasa Indonesia. Jakarta: Balai Pustaka.

Gunawan, Imam. (2013) Metode Penelitian Kualitatif Teori dan Praktik. Jakarta: Bumi Aksara.

Kaswardi, EMK. (1988). Pendidikan Nilai Memasuki Tahun 2000. Jakarta: Gramedia Widiasarana Indonesia.

Lincoln And Guba. (1985). Naturalistic Inquiry. California: Sage Publication.

Makbuloh, Deden. (2012). Pendidikan Agama Islam Arah Baru Pengembangan Ilmu dan Kepribadian di Perguruan Tinggi, Jakarta: Rajawali Pers.

Muhajir, As'aril. (2011). Ilmu Pendidikan Perspektif Kontekstual. Jogjakarta: Ar-Ruzz Media.

Mujib, Abdul. (2008). Ilmu Pendidikan Islam, (Jakarta: Kencana.

Noer Aly, Hery. (1999). Ilmu Pendidikan Islam. Jakarta: PT. Logos Wacana Ilmu.

Nurdin, Muhammad. (2014). Pendidikan Anti Korupsi: Strategi Internalisasi Nilai-nilai Islami dalam Menumbubkan Kesadaran Antikorupsi di Sekolah. Yogjakarta: Ar-Ruzz Media.

Poerwadarminta, W. J. S. (1986). Kamus Bahasa Indonesia. Jakarta: Balai Pustaka.

Quthb, Muhammad. (1993). Sistem Pendidikan Islam. Bandung: PT. Al Ma'arif.

Saebani, Ahmad dan Hamid, Abdul. (2010). Ilmu Akhlak. Bandung: Pustaka Setia.

Sarkonah. (2012). Panduan Pramuka Penggalang. Bandung: Nuansa Aulia.

Syafaat, Aat., Sahrani, Sohari., dan Muslih. (2008). Peranan Pendidikan Agama Islam Dalam Mencegah Kenakalan Remaja (Juvenile Delinquency). Jakarta: Rajawali Pers.

Syah, Muhibbin. (2014). Psikologi Pendidikan Dengan Pendekatan Baru. Bandung: PT. Remaja Rosdakarya.

Tafsir, Ahmad. (2008). Ilmu Pendidikan Dalam Perspektif Islam. Bandung: Remaja Rosdakarya Offset. Tafsir, Ahmad. (2013). Imu Pendidikan Islam. Bandung: PT. Remaja Rosdakarya.

Uhbiyati, Nur. (1998). Ilmu Pendidikan Islam. Bandung: Pustaka Setia.

Undang-Undang Sistem Pendidikan Nasional. (2003). Yogyakarta: Media Wacana.

Wahyudi, Imam. (2012). Mengejar Profesionalisme Guru Strategi Praktis Mewnjudkan Citra Guru Profesional. Jakarta: Pretasi Pustaka.

Zulkarnain. (2008). Transformasi Nilai-Nilai Pendidikan Islam. Yogyakarta: Pustaka Pelajar. 